\title{
PENINGKATAN PENGGUNAAN PAST TENSE DALAM TEXT RECOUNT MELALUI MODEL STAD PADA SISWA
}

\author{
Dewi Khotidjah \\ SMP Negeri 1 Giriwoyo \\ nurmudisapawi@yahoo.co.id
}

\begin{abstract}
Abstrak
Tujuan penelitian ini adalah untuk mengetahui kemampun penggunaan kosa kata bentuk kedua yang akan digunakan dalam pembuatan text recount bagi siswa kelas VIIIB SMP Negeri 1 Giriwoyo Wonogiri tahun 2015/2016. Penelitian ini menggunakan metode penelitian tindakan kelas (PTK). Penelitian ini terdiri dari tiga siklus, setiap siklus terdiri dari empat tahap yaitu: planning,acting, observing dan reflecting. Metode pengumpulan data penelitian menggunakan intrumen Tes, observasi, dan dokumentasi. Subjek penelitian ini yaitu siswa kelas VIIIB SMP Negeri 1 Giriwoyo yang berjumlah 28 siswa. Hasil penelitian menunjukkan bahwa terdapat peningkatan kemampuan penggunaan kosa kata bentuk kedua setelah tindakan. Terdapat peningkatan nilai sebesar $53,60 \%$ pada siklus I dan $29,4 \%$ pada silus II. Berdasarkan hasil tersebut dapat mengambil kesimpulan bahwa model pembelajaran STAD yang diterapkan berhasil meningkatkan kemampuan siswa menggunakan kata kerja kedua ( past-tense) dalam text recount.
\end{abstract}

Kata Kunci: Past Tenses, Text Recount, Model STAD

\section{Abstract}

The purpose of this study was to determine the ability to use the second form of vocabulary that will be used in making text recounts for grade VIIIB students of SMP Negeri 1 Giriwoyo Wonogiri in 2015/2016. This study uses a classroom action research (CAR) method. This study consisted of three cycles, each cycle consisting of four stages: planning, acting, observing and reflecting. Research data collection methods using test instruments, observations, and documentation. The subjects of this study were 28th grade students of SMP Negeri 1 Giriwoyo, totaling 28 students. The results showed that there was an increase in the ability to use second form of vocabulary after the action. There was an increase in value of $53.60 \%$ in the first cycle and $29.4 \%$ in the second series. Based on these results it can be concluded that the STAD learning model applied successfully improves students' ability to use the second verb (past - tense) in the recount text.

Keywords: Past Tenses, Recount Text, STAD Model

\section{PENDAHULUAN}

Manusia hidup bermasyarakat membutuhkan bahasa. Bahasa mempunyai fungsi sebagai alat komunikasi baik secara lisan atau tertulis. Bahasa adalah satu alat yang membantu orang berkomunikasi diantara individu maupun bangsa, sejak fungsi bahasa dijadikan sebagai alat komunikasi. Itu artinya bahasa adalah satu cara mentransfer informasi tertentu, ide, pendapat, pikiran dari satu orang ke orang lain. Dalam kenyataan sehari-hari manusia saling berkomunikasi dengan manusia lainnya dengan menggunakan bahasa. Jadi bahasa mempunyai peranan penting agar orang dapat mengadakan kontak dengan orang lain. Bahasa terdiri dari bentuk, ucapan, dan tulisan. Tujuan dari pengajaran bahasa asing atau bahasa kedua biasanya menetapkan empat bentuk ketrampilan bahasa yaitu: Speaking, Listening, Reading, and Writing.

Sebagai alat komunikasi, bahasa digunakan untuk menyatakan berbagai macam tindakan. Bahasa dapat digunakan untuk membuat pernyataan, membuat teks, mengajukan pertanyaan, memberi perintah, mengungkapkan suatu hal, menyatakan komitmen, dan melakukan tugas lainnya. Agar dapat menggunakan 
bahasa untuk berbagai tujuan dengan tepat, diperlukan penguasaan kosakata yang lebih banyak.

Mengacu pada empat ketrampilan bahasa yang banyak memerlukan kosa kata adalah pembuatan teks, kosa kata yang digunakan harus disesuaikan dengan jenis teks yang akan ditulis, terutama pada kata kerjanya, jenis teks yang dipelajari di kelas VIII yaitu descriptip, recount, narrative. Pada penelitian ini menggunakan text recount. Pada jenis text ini kata kerja yang digunakan adalah kata kerja bentuk kedua (past form). Unsur bahasa yang dipakai untuk membuat text recount meliputi pola kalimat, penguasaan kosa kata dan tenses yang tepat. Penguasaan bahasa dan unsur bahasa digunakan sesuai dengan jenis teks, menuntut siswa mengenal pola-pola kalimat dan kosa kata yang digunakan untuk tujuan tersebut. Sebagai bahasa internasional, bahasa Inggris berperanan penting. Ia digunakan dibidang sosial, ekonomi dan pengetahuan alam. Ia digunakan hampir diseluruh dunia, termasuk Indonesia.

Di Indonesia bahasa Inggris diajarkan sebagai bahasa asing pertama, yang artinya untuk menstranfer pengetahuan dan tehnologi bagi perkembangan negara, dan sebagai alat untuk membangun hubungan internasioal yang menjadi tuntutan era globalisasi. Dalam mempelajari bahasa asing seperti bahasa Inggris tidaklah mudah, karena setiap bahasa mempunyai sistem sendiri-sendiri. Ketika mempelajari bahasa Inggris, siswa mempunyai kesulitan yang berbeda karena banyak perbedaan antara bahasa asing dan bahasa ibu.

Menulis sebagai salah satu aspek dari 4 ketrampilan bahasa sangat penting untuk dipelajari. Menulis sebuah karya ilmiah tidak bisa dilakukan secara instan (Nurgiansah, 2020). Tulisan harus mempunyai 3 tujuan, hal ini dihubungkan Robert Borenus (1956: 5) dalam bukunya yang berjudul Pattern In Writing, yaitu:1)
Memberi penjelasan dan latihan kepada siswa dalam hal seni dan kerangka karangan. 2) Menyediakan kesempatan dan bimbingan untuk membaca cermat dan cerdas. 3) Memperluas pengertian dan membuktikan kehebatan berpikir mereka.

Pelajaran bahasa Inggris yang terdiri dari 4 ketrampilan memerlukan kosa kata, karena kosa kata adalah bagian dari bahasa. Bagi siswa penguasaan kosa kata sangatlah penting. Siswa yang menguasai kosa kata lebih mudah mempelajari bahasa Inggris. Mereka dapat menuangkan kemampuan berpikir dan menyatakan ide mereka dalam speaking dan writing. Penguasaan kosa kata sangat perlu ketika membuat sebuah teks, jika tidak mereka akan kesulitan.

Speaking dan writing adalah proses terjadinya komunikasi, pikiran, ide, atau perasaan dari bahasa yang satu ke bahasa lain, sedangkan listening dan reading adalah proses uraian sejajar sebagai pesan tertulis dan langsung. Kurikulum KTSP Bahasa Inggris SMP (Depdiknas 2006) menyatakan bahwa pengajaran Bahasa Inggris di SMP ditujukan untuk mengembangkan kemampuan berkomunikasi dalam bahasa Inggris. Salah satu aspek yang dikembangkan untuk membekali siswa adalah writing, agar siswa mampu menulis teks recount dengan menggunakan kosa kata dan pola kalimat yang benar.

Pengamatan awal di SMP Negeri 1 Giriwoyo menunjukkan bahwa penguasaan siswa terhadap pola kalimat, kosa kata dan bentuk waktu belum memuaskan. Mereka sudah dikenalkan dengan pola-pola kalimat, tetapi belum dapat menerapkannya dalam membuat text recount seperti yang diharapkan. Pemahaman terhadap pola-pola kalimat dalam text recount belum dapat dikuasai oleh siswa dengan baik, karena siswa belum menguasai kata kerja dalam bentuk lampau sehingga mereka mengalami kesulitan dalam menulis text jenis ini. 
Idealnya siswa diberikan pengalaman sebenarnya untuk menggunakan pola-pola kalimat dan kosakata yang benar dalam text recount, oleh sebab itu siswa perlu diberikan latihan membuat text jenis recount di rumah maupun di sekolah dengan menggunakan pola kalimat dan struktur yang benar. Mengingat hal tersebut maka peneliti ingin mengadakan penelitian tentang Upaya Peningkatan Kemampuan Menggunakan Kosa Kata Bentuk lampau (Past Tense) Dalam Text Recount Melalui Model STAD Pada Siswa Kelas VIII B SMP Negeri 1 Giriwoyo Wonogiri Semester Genap Tahun Pelajaran 2015 / 2016.

\section{METODE PENELITIAN}

Penelitian ini dilaksanakan di SMP Negeri 1 Giriwoyo Wonogiri Semester Genap Tahun Pelajaran 2015 / 2016. Sementara itu Instrumen yang digunakan dalam penelitian ini yaitu tes, observasi dan dokumentasi. Subyek penelitian adalah siswa kelas VIII B SMP Negeri 1 Giriwoyo tahun pelajaran 2015/2016 yang terdiri dari 28 siswa dengan komposisi laki-laki 19 siswa dan perempuan 9 siswa. Penelitian ini menggunakan metode penelitian tindakan kelas (PTK) yang terdiri dari tiga siklus yaitu siklus I, siklus II, dan Siklus III. Penelitian Tindakan Kelas merupakan penelitian yang mengangkat masalah-masalah yang aktual yang terjadi di kelas (Nurgiansah, 2021). Tujuan PTK sendiri adalah untuk meningkatkan dan/atau memperbaiki praktik pembelajaran di sekolah (Nurgiansah et al., 2021).

Teknik yang digunakan untuk memeriksa validasi data dalam penelitian ini adalah triangulasi dan review informan. Maleong (2004: 330) mengemukakan bahwa triangulasi adalah teknik pemeriksaan keabsahan data yang memanfaatkan sesuatu yang lain di luar data itu untuk keperluan pengecekan atau sebagai pembanding terhadap data itu. Tehnik analisis data yang digunakan dalam penelitian ini adalah tehnik analisis comparatif, yang meliputi: Analisis komparatif prestasi belajar dengan cara membandingkan prestasi belajar pada pra tindakan, siklus 1 , siklus 2, siklus 3 . Untuk mengukur keberhasilan tindakan yang dilakukan, penulis memandang perlu adanya indikator kinerja. Indikator kinerja ini, ditentukan berdasarkan rerata nilai hasil pre-test yang peneliti lakukan sebelum tindakan dilaksanakan dikelas dan rerata nilai ulangan harian dari dokumen guru pengampu. mata pelajaran bahasa Inggris kelas VIII. Peneliti juga mempertimbangkan standar ketuntasan belajar minimal untuk mata pelajaran bahasa Inggris kelas VIII.

\section{HASIL PENELITIAN DAN PEMBAHASAN Hasil Penelitian Deskripsi Kondisi Awal}

Hasil pengamatan awal mengenai dapat aktivitas siswa dicari rata-rata persentase yang hasilnya sebagai berikut:

Tabel 1. Rekapitulasi Aktivitas Siswa Pratindakan

\begin{tabular}{|c|c|c|c|c|}
\hline \multirow{2}{*}{ No } & \multirow{2}{*}{$\begin{array}{c}\text { Apek yang } \\
\text { diamati }\end{array}$} & \multicolumn{2}{|c|}{ Jumlah Siswa } & \multirow{2}{*}{$\begin{array}{c}\text { Persen- } \\
\text { tase }\end{array}$} \\
\cline { 3 - 4 } 2 & $\begin{array}{c}\text { Kegairahan } \\
\text { belajar }\end{array}$ & 11 & 17 & $37 \%$ \\
\hline 2 & $\begin{array}{c}\text { Menunjukan } \\
\text { suasana } \\
\text { gembira }\end{array}$ & 11 & 17 & $37 \%$ \\
\hline 3 & $\begin{array}{c}\text { Rajin } \\
\text { menjawab } \\
\text { pertanyaan } \\
\text { guru }\end{array}$ & 11 & 17 & $37 \%$ \\
\hline 4 & $\begin{array}{c}\text { Hubungan } \\
\text { antar teman }\end{array}$ & 9 & 19 & $30 \%$ \\
\hline 5 & $\begin{array}{c}\text { Semangat } \\
\text { dalam } \\
\text { mengerjakan } \\
\text { tugas }\end{array}$ & 8 & 20 & $29 \%$ \\
\hline 6 & $\begin{array}{c}\text { Keinginan } \\
\text { untuk tampil di } \\
\text { depan kelas }\end{array}$ & 8 & 20 & $29 \%$ \\
\hline \multicolumn{3}{|c|}{ Rata-rata aktivitas siswa } & $33,2 \%$ \\
\hline
\end{tabular}


Sumber: Diolah peneliti (Juni 2021)

Berdasarkan data di atas diperoleh rata-rata aktivitas siswa sebesar 33,2\%. Artinya untuk setiap aspek yang diamati hanya ada $33,2 \%$ dari jumlah siswa sebanyak 28 yang menunjukkan keadaan yang ideal. Sedangkan sisanya sebesar $61,38 \%$ belum menunjukkan keadaan yang diinginkan. Rendahnya aktivitas siswa dalam pembelajaran ini disebabkan guru hanya meminta siswa membaca LKS dan mengerjakan latihan yang ada pada LKS tersebut, hal ini menimbulkan masalah keterlibatan siswa yang sangat beragam. Kondisi anak-anak cenderung pasif, sulit diajak komunikasi dan terlihat apatis mengikuti pelajaran.

Selanjutnya, berdasarkan hasil tes yang dilakukan pada pratindakan diperoleh prestasi yang rendah, tabel berikut menunjukkan hasil prestasi belajar pratindakan. Dari 28 siswa hanya ada 2 siswa yang tuntas KKM yang telah ditetapkan sebesar 75 . Nilai rata-rata siswa hanya sebesar 50,28 dan nilai tertinggi yang diperoleh siswa sebesar 75. Sebagian besar siswa belum mencapai ketuntasan belajar, hanya sebagian kecil yang telah mencapai ketuntasan belajar. Rendahnya prestasi belajar ini disebabkan guru hanya meminta siswa membaca LKS dan mengerjakan latihan soal yang ada pada LKS tersebut, hal ini berdampak pada rendahnya prestasi belajar sebagaimana tercantum pada tabel tersebut.

\section{Pembahasan Siklus I}

Berdasarkan Hasil tindakan siklus I, dapat dilihat ada peningkatan prestasi belajar siswa sesudah tindakan siklus 1 . Rata-rata kelas (ketercapaian) meningkat dari $5.5 \%$ menjadi $63.88 \%$.Siswa tuntas belajar meningkat dari $2(5.5 \%)$ menjadi 20 (63.88\%), Namun masih perlu ada tindakan kedua dengan penyempurnaan sebagaimana hasil refleksi siklus pertama.

\section{Siklus II}

Hasil tindakan siklus kedua, prestasi siswa secara individual dapat dilihat ada peningkatan prestasi belajar siswa sesudah tindakan siklus 2. Rata-rata kelas ( ketercapaian) meningkat dari 59.86 menjadi 73.05. Siswa tuntas belajar meningkat dari 19 (63.88\%) menjadi 28 $(77.77 \%)$, namun masih perlu ada tindakan ketiga dengan penyempurnaan sebagaimana hasil refleksi siklus kedua.

\section{Siklus III}

Hasil tindakan siklus ketiga secara individu dapat dilihat ada peningkatan signifikan pretasi belajar siswa sesudah tindakan siklus 3. Rata kelas ketercapaian meningkat dari 73 menjadi 93.47. Siswa belajar tuntas meningkat dari $28(77.77 \%)$ menjadi 35 (97.22\%). Dari hasil tersebut diatas dapat dibuat grafik perbandingan rata-rata prestasi siswa pada siklus 1,2 dan 3 adalah sebagai berikut.

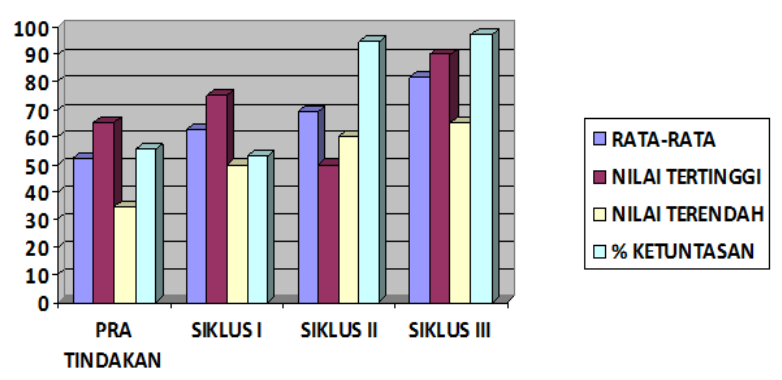

Gambar 1. Perkembangan Prestasi belajar Siswa

Berdasarkan hasil olahan data tersebut, dapat disimpulkan bahwa telah terjadi peningkatan ketuntasan belajar yaitu dari pratindakan sebesar 5,55\%, siklus I sebesar $52,77 \%$, siklus II sebesar $94,44 \%$ dan siklus III sebesar 97,22\%. Selain itu nilai rata-rata siswa juga mengalami peningkatan yaitu dari pratindakan sebesar 52,50, siklus I sebesar 62,78 , siklus II sebesar 69,30 dan siklus III sebesar 97,22.

Adapun target penelitian ini diharapkan tercapai persentase ketuntasan 
belajar sebesar 90\%. Dengan melihat hasil pada akhir siklus III diperoleh ketuntasan belajar sebesar 97,22\%, dengan demikian dapat dikatakan penelitian ini telah berhasil. Demikian juga dengan perkembangan nilai terendah dan nilai tertinggi mengalami perkembangan yang positif sebagaimana terlihat pada tabel dan grafik di atas.

Peningkatan prestasi belajar siswa ini menunjukkan bahwa penerapan model STAD telah memberikan peningkatan prestasi belajar siswa. peningkatan prestasi belajar ini karena telah terjadi efektifitas belajar. Efektivitas pembelajaran banyak bergantung kepada kesiapan dan cara belajar yang dilakukan oleh siswa itu sendiri, baik yang dilakukan secara mandiri maupun kelompok. Dalam hal ini, ditekankan pentingnya upaya pengembangan aktivitas, kreativitas, dan motivasi siswa di dalam proses Pembelajaran.

\section{KESIMPULAN}

Dari penelitian ini dapat disimpulkan bahwa: Penerapan model pembelajaran STAD (Student Teams Achievement Divisions) dapat meningkatkan prestasi belajar bahasa Inggris khususnya pembuatan text recount dan ada peningkatan penggunaan kosa kata bentuk kedua (past form) dalam menceritakan pengalaman masa lalu tentang berbagai hal. Ada peningkatan penggunaan kosa kata bentuk kedua (past form) dalam menceritakan masa lalu tentang kesehatan. Besarnya peningkatan ketuntasan belajar yaitu dari pratindakan sebesar 5,5\%, Siklus 1 sebesar 63,88\%, siklus II sebesar $77,77 \%$, dan siklus II sebesar 97,22\%. Kosa kata bentuk past tense dengan pembuatan teks jenis recount pada siswa SMP Negeri 1 Giriwoyo tahun 2014.

Selanjutnya, berikut terdapat beberapa saran yang ditujukan untuk berbagai pihak: Guru harus memberi motivasi yang lebih kepada siswa untuk menyatakan ide mereka dalam bentuk karangan, khususnya menulis text recount, dengan cara itu siswa mampu memperluas perbendaharaan kata mereka. Siswa harus menyadari bahwa penguasan kosa kata adalah kunci sukses dalam menguasai 4 ketrampilan bahasa Inggris, maka siswa harus mempelajarinya sebanyak mungkin. Peneliti Lain dapat melakukan penelitian lebih lanjut untuk memperoleh hasil inovasi pembelajaran yang lebih bervariasi.

\section{DAFTAR PUSTAKA}

Agus Supriyono. 2010. Cooperative Learning. Surabaya: Pustaka Pelajar

Arikunto, Suharsini. 2010. Penelitian Tindakan Untuk guru, Kepala sekolah dan Pengawas. Yogyakarta: Aditya Media.

Depdiknas. 2006. Kurikulum KTSP Bahasa Inggris SMP. Jakarta: Departemen Pendidikan Nasional

Echols, John M. dan Hassan Shadily. 2005. Kamus Inggris Indonesia: An English - Indonesian Dictionary. Jakarta: PT Gramedia

Hamalik, Oemar. 2001. Proses Belajar Mengajar. Jakarta: Bumi Aksara

Harris, D.V. 1969. Testing as a second language. USA: McGraw-Hill, Inc.

Isjoni. 2009. Cooperative Learning Mengembangkan Kemampuan Belajar Berkelompok, Bandung : Alfabeta

Iskandar. 2009. Penelitian Tindakan Kelas, Jakarta: Gaung Persada Press

Moleong Lexy J. 2004. Metodologi Penelitian Kualitatif. Bandung: Remaja Rosdakarya

Nasution, S. 1999. Kurikulum dan Pengajaran. Jakarta: Bumi Aksara

Nurgiansah, T. H. (2020). Pelatihan Penulisan Artikel Ilmiah Bagi Mahasiswa PPKn Universitas 
PGRI Yogyakarta. JNPM: Jurnal Nasional Pengabdian Masyarakat, 1(1), 16-23.

Nurgiansah, T. H. (2021). Pelatihan Penelitian Tindakan Kelas Bagi Guru Pendidikan Kewarganegaraan Di Sekolah Menengah Atas Se-Kabupaten Bantul. BERNAS: Jurnal Pengabdian Kepada Masyarakat, 2(1), 28-33. https://doi.org/10.31949/jb.v2i1.566

Nurgiansah, T. H., Pratama, F. F., \& Iman, A. S. (2021). Penelitian Tindakan Kelas Dalam Pendidikan Kewarganegaraan. Jurnal Pendidikan Pancasila Dan Kewarganegaraan, 2(1), 10-23. 